\title{
Infekcinio encefalito diagnostika ir gydymas imunosupresinių būklių metu: klinikinio atvejo pristatymas ir literatūros apžvalga
}

\author{
M. Jokubaitis* \\ J. Valaikiené** \\ *Vilniaus universiteto \\ Medicinos fakultetas \\ **Vilniaus universiteto \\ Medicinos fakultetas, \\ Klinikines medicinos instituto \\ Neurologijos centras
}

\begin{abstract}
Santrauka. Infekcinis encefalitas imunosupresinių būklių metu yra neretai pasitaikanti, greitos diagnostikos ir ankstyvo gydymo reikalaujanti būklè, galinti sąlygoti sunkų neurologinị deficitą ir net ligonio mirtị. Ši problema tampa itin aktuali didejant sergamumui onkologinėmis ir autoimuninėmis ligomis, kurios yra gydomos imunosupresiniu poveikiu pasižyminčiais vaistais. Esant imunosupresinei būklei, infekcinio encefalito diagnostika yra sudètinga, nes klinikiniai simptomai, laboratorinių ir instrumentinių tyrimų pokyčiai dažnai yra silpniau išreikšti ar imituojantys neinfekcinès kilmės susirgimus. Todèl imunosupresiniams ligoniams, kuriems staiga pasireiškia neurologinè židininė simptomatika, būtina ịtarti neuroinfekciją, net ir nesant encefalitui būdingų klinikinių požymių. Laiku nustačius infekcinio encefalito diagnozę ir pradejus gydymą, gerejja ligos prognozé. Šiame straipsnyje pristatomas sudètingas netipinis klinikinis atvejis, kai $62 \mathrm{~m}$. ligoniui, sergančiam mielomine liga, ūmus meningoencefalitas debiutavo insultui būdinga klinika. Taip pat apžvelgiama literatūra, susijusi su infekcinio encefalito klinikiniu pasireiškimu, diagnostika ir gydymo rekomendacijomis imunosupresinių būklių metu.
\end{abstract}

Raktažodžiai: neuroinfekcija, encefalitas, imunosupresija, diagnostika, gydymas.

\section{IVADAS}

Naujausios literatūros duomenimis, encefalito dažnis siekia iki 12,6 atvejo 100000 gyventojų per metus, apie $50 \%$ jų yra infekcinès kilmès, 20-30 \% - autoimuniniai, likę nenustatytos etiologijos [1-3]. Prancūzijoje atlikto perspektyvinio tyrimo duomenimis, dažniausi infekcinio encefalito sukẻlëjai yra Herpes simplex virusas (HSV) (42\%), Varicella zoster virusas (VZV) (15\%), Mycobacterium tuberculosis $(15 \%)$ ir Listeria monocytogenes $(10 \%)$ [4]. Būdingi klinikiniai encefalito požymiai yra karščiavimas, naujai atsiradę traukuliai ir židininè neurologinė simptomatika [1]. Imunosupresinių (angl. immunosuppressed) ligonių centrinès nervų sistemos (CNS) infekcijų diagnostika yra sudètinga, nes jiems minèti klinikiniai

\author{
Adresas: \\ Mantas Jokubaitis \\ Vilniaus universiteto Medicinos fakultetas \\ M. K. Čiurlionio g. 21, LT-03101 Vilnius \\ El. paštas mantas.jokubaitis1@gmail.com
}

simptomai ir požymiai gali nepasireikšti, o laboratoriniai ir instrumentiniai duomenys - būti netipiniai [5]. Neretai imunosupresinių ligonių infekcinio encefalito sukèlejjai yra nebūdingi imunokompetentiniams (angl. immunocompetent) asmenims, o imunosupresinių ligonių, sergančių infekciniu encefalitu, mirtingumas yra didesnis, lyginant su imunokompetentiniais, nepriklausomai nuo ligos sukèlèjo $[6,7]$. Dvi didžiausios imunosupresinių, kartu ir didelès infekcinio encefalito rizikos, ligonių grupès yra sergantieji onkologinemis ligomis ir ligoniai, vartojantys imunosupresinius vaistus [5].

\section{ATVEJO APRAŠYMAS}

$62 \mathrm{~m}$. vyras skubiai atvežtas ị artimiausią insulto centrą dèl ryte pastebėto kalbos sutrikimo. Neurologinès apžiūros metu nustatyta dalinè sensomotorinè afazija ir lengvo laipsnio dešinioji hemiparezè. Atlikus skubią galvos smegenų kompiuterinę tomografiją (GSKT), ūmių pakitimų nenustatyta. Diagnozuotas ūmus galvos smegenų insultas

(C) Neurologijos seminarai, 2019. Open Access. This article is distributed under the terms of the Creative Commons Attribution 4.0 International License CC-BY 4.0 (http://creativecommons.org/licenses/by/4.0/), which permits unrestricted use, distribution, and reproduction in any medium, provided you give appropriate credit to the original author(s) and the source, provide a link to the Creative Commons license, and indicate if changes were made. 
kairiosios vidurinės smegenų arterijos baseine. Išsiaiškinus, kad ligonis serga mielomine liga ir aktyviai gydomas Vilniaus universiteto ligoninès Santaros klinikų (VUL SK) hematologų (vartoja talidomidą), intraveninès trombolizės protokolas netaikytas. Ligonis nedelsiant persiųstas ị VUL SK. Apžiūrint ligonị prièmimo skyriuje, arterinis kraujo spaudimas buvo $115 / 80 \mathrm{mmHg}$, širdies susitraukimų dažnis - 67 kartai per minutę, širdies veikla - ritmiška. Pakartotinès neurologinès apžiūros metu konstatuota sensomotorinè afazija, dešiniosios rankos motorikos sutrikimas, meninginiai simptomai buvo neigiami. Itariant ūmų galvos smegenų kraujotakos sutrikimą, ligonis skubos tvarka hospitalizuotas ị VUL SK Neurologijos skyrių. Dėl protrombozinio talidomido poveikio, jo skyrimas nutrauktas. Ligonis gydytas aspirinu ir fraksiparinu. Praejjus 12 valandų, ligoniui prasidejo toninių-kloninių traukulių priepuoliai. Taikytas gydymas diazepamu buvo neefektyvus, išsivystè epilepsinè būklè, ligonis buvo skubiai perkeltas į Reanimacijos ir intensyviosios terapijos skyrių.

Bendrajame kraujo tyrime buvo nustatyta neutrofilinè leukocitozè (leukocitai - 10,6×109/1), anemija ( HgB $79 \mathrm{~g} / \mathrm{l})$, biocheminiuose kraujo tyrimuose $-\mathrm{C}$ reaktyviojo baltymo $(180,7 \mathrm{mg} / \mathrm{l})$ ir prokalcitonino $(2,95 \mu \mathrm{g} / \mathrm{l}) \mathrm{kon}$ centracijos padidejjimas, bendrasis šlapimo tyrimas atitiko normą. Atlikus krūtinès ląstos rentgenografiją, uždegiminių pokyčių nenustatyta. Pakartojus GSKT, duomenų, leidžiančių įtarti galvos smegenų hemoragiją ar išemiją, taip pat nenustatyta. İtarus neuroinfekciją, atlikta juosmeninè punkcija, gautas skaidrus likvoras, kuriame nustatytas padidèjęs leukocitų skaičius (571 ląstelių/ $\mu$ l), vyraujant neutrofilams (54\%). Tuberkuliozès mikobakterijų mikroskopuojant nerasta. Biocheminiame likvoro tyrime rastas gliukozès koncentracijos sumažèjimas $(1,75 \mathrm{mmol} / \mathrm{l})$ ir baltymo koncentracijos padidejjimas $(4,92 \mathrm{~g} / \mathrm{l})$. Ligonis konsultuotas hematologo dèl tolimesnès diagnozuotos mielominès ligos (IgG kappa variantas, III stadija) gydymo. Ciklofosfamido, talidomido, deksametazono (CTD) chemoterapijos kursas nukeltas iki būklès stabilizavimo. Paskirtas papildomas likvoro ištyrimas dẻl atipinių virusinių sukėlèjų, tèkmės citometrija. Diagnozavus bakterinị meningoencefalitą, ligonis pradètas gydyti meropenemu 2 g 3 kartus per dieną, gydytas 15 dienų.

Pakartojus likvoro punkciją, stebèta teigiama dinami-

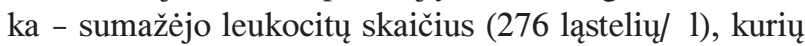
$24 \%$ sudarè neutrofilai, $25 \%$ - monocitai, $2 \%$ - limfocitai ir $49 \%$ - plazminès ląstelès. Leptomeninginès karcinomatozès diagnozé, atlikus likvoro plazminių ląstelių tėkmės citometrijos tyrimą, buvo paneigta. Likvoro serologiniai tyrimai dèl HSV IgM antikūnų buvo neigiami, o atliekant molekulinius tyrimus dèl gripo, citomegalo virusų, adenoviruso, Herpes 1, 2, 6 ir 8 virusų, enterovirusų, jų DNR ir RNR neaptikta. Kraujo ir likvoro pasėliuose bakterijų bei grybelių augimo nebuvo. Atlikus trečiają GSKT ir nenustačius išeminių pakitimų, paneigtas ir ūmus galvos smegenų infarktas. Ligonis konsultuotas otorinolaringologo ir odontologo, kurie atmetė ausų, nosies ir gerklès organų bei dantų infekcijos židinius. Dėl besikartojančių traukulių, skirtas gydymas karbamazepinu 100 mg 3 kartus per dieną.

Ligonio būklei pagerejus - regresavus kalbos sutrikimui, hemiparezei, po trijų savaičių jis buvo išrašytas ir nukreiptas hematologo konsultacijai dèl tolimesnès mielominès ligos gydymo. Po mènesio atnaujinta CTD chemoterapija, baigus 4 gydymo kursus pasiekta labai gera dalinè mielominès ligos remisija. Siekiant pailginti išgyvenamumą, po keturių mėnesių ligoniui buvo sėkmingai atlikta autologinè kraujodaros kamieninių ląstelių transplantacija. Gauta pirma mielominès ligos remisija. Po dvejų su puse metų mielominès ligos remisija išlieka, neurologinė būklè - be patologinių pokyčių.

\section{INFEKCINIO ENCEFALITO APIBRĖŽIMAS IR DIAGNOSTINIAI KRITERIJAI}

Infekcinis encefalitas yra apibrèžiamas kaip galvos smegenų parenchimos uždegimas, esant klinikiniams neurologinès disfunkcijos požymiams [8]. $2013 \mathrm{~m}$. tarptautinis encefalito konsorciumas paskelbè encefalito diagnostikos kriterijus (1 lentelè). Galimam encefalitui (angl. possible encephalitis) diagnozuoti būtinas vienas didysis kriterijus ir du mažieji kriterijai, tikėtinam encefalitui (angl. probable encephalitis) - vienas didysis ir trys mažieji kriterijai, o patvirtinto encefalito diagnozei - encefalito patvirtinimas patologinio tyrimo metu ir (arba) patologiniai, mikrobiologiniai ar serologiniai pokyčiai, būdingi ūmiai infekcijai su nustatytu mikroorganizmu, galinčiu sukelti encefalitą [9].

1 lentelè. Diagnostiniai infekcinès kilmės encefalito kriterijai

\begin{tabular}{||l||}
\hline Didysis kriterijus (būtinas) \\
\hline $\begin{array}{l}\text { 1) Protinės būklès sutrikimas, kuris pasireiškia sumažejusiu } \\
\text { ar pakitusiu sąmonės lygiu, mieguistumu ar asmenybės } \\
\text { pokyčiais ir trunka } 24 \text { valandas ar ilgiau, nesant } \\
\text { alternatyvios encefalitui priežasties. }\end{array}$ \\
\hline Mažieji kriterijai \\
\hline $\begin{array}{l}\text { 1) Karščiavimas - } \geq 38^{\circ} \mathrm{C} \text {, pasireiškęs per } 72 \text { valandas prieš } \\
\text { (po) ligos pasireiškimą. }\end{array}$ \\
\hline $\begin{array}{l}\text { 2) Generalizuoti arba židininiai epilepsijos priepuoliai, kurie } \\
\text { negali būti priskiriami prieš tai buvusiam epilepsiniam } \\
\text { sindromui. }\end{array}$ \\
\hline 3) Naujai pasireiškę židininiai neurologiniai simptomai. \\
\hline 4) Leukocitų skaičius likvore - $\geq 5 /$ mm ${ }^{3}$. \\
\hline $\begin{array}{l}\text { 5) Encefalitui būdingi naujai atsiradę smegenų parenchimos } \\
\text { pokyčiai kompiuterinès tomografijos ar magnetinio } \\
\text { rezonanso tomografijos vaizduose. }\end{array}$ \\
\hline 6) Pakitimai elektroencefalogramoje, leidžiantys įtarti \\
encefalitą ir neturintys kito paaiškinimo.
\end{tabular}

Pagal Venkatesan A, Tunkel AR, Bloch KC, et al. Case definitions, diagnostic algorithms, and priorities in encephalitis: consensus statement of the international encephalitis consortium. Clin Infect Dis 2013; 57: 1114-28. 


\section{INFEKCINIO ENCEFALITO PASIREIŠKIMAS IR LIGOS SUKE்LE்JŲ DIAGNOSTIKA}

Nepaisant pažangių šiuolaikinės diagnostikos galimybių, apie pusę visų infekcinio encefalito atvejų ligos sukèlèjas lieka nežinomas [2]. I šią kategoriją pakliūna ir aprašytas ligonis, kuriam atlikus išsamius kraujo ir likvoro tyrimus, ligos sukèlèjas nebuvo nustatytas. Tais atvejais, kai pavyksta nustatyti infekcinio encefalito sukèlèją, dominuoja virusinè etiologija.

HSV yra dažniausias infekcinio encefalito (meningoencefalito) sukèlèjas [2]. Nors HSV encefalitas dažnai pasireiškia imunokompetentiniams asmenims, o HSV paprastai nėra laikomas oportunistiniu sukèleju, daugejja tyrimų, irodančių galimą ryšį tarp HSV encefalito išsivystymo ir imunosupresinių vaistų vartojimo $[10,11]$. Taip pat pastebėta, kad vėžiu sergantiems ligoniams, kurie gydyti galvos smegenų radioterapija ir deksametazonu, HSV encefalito išsivystymo rizika smarkiai išaugo (1 iš 250), lyginant su bendraja populiacija, kurioje HSV encefalito rizika siekia 2-4 iš 1000000 [12]. HSV encefalitas imunosupresiniams ligoniams, lyginant su imunokompetentiniais ligoniais, pasireiškia silpniau išreikštu prodromo laikotarpiu, retesniais židininiais neurologiniais simptomais, mažesne pleocitoze likvore ir labiau išreikštu medialinès smilkininès skilties pažeidimu neurovizualiniuose tyrimuose - infekcija neretai kartu apima ir smegenų kamieną bei smegenèles [11,13-15]. Abipusis smilkininių skilčių pažeidimas yra itin būdingas HSV encefalito požymis. HSV encefalito diagnozei patvirtinti atliekama polimerazès grandininè reakcija (PGR) HSV DNR likvore nustatyti [8].

Imunosupresija yra vienas iš VZV reaktyvacijos rizikos veiksnių. Mokslinėje literatūroje aprašomi klinikiniai atvejai, kuriuose su didesne VZV encefalito rizika siejami tumoro nekrozès faktoriaus alfa inhibitoriai, organu transplantacija ir onkochemoterapinių vaistų vartojimas [16-19]. Imunosupresinių ligonių VZV encefalitui ypač būdinga CNS kraujagyslių vaskulopatija, pasireiškianti didžiụjų kraujagyslių arteritu ir (arba) mažo ploto išeminiais insultais su demielinizacijos židiniais $[8,20]$. VZV encefalito metu magnetinio rezonanso tomografijos (MRT) vaizduose dažnai matomi hiperintensiniai ir homogeniški kontrastą kaupiantys periventrikuliniai židiniai T2 sekoje [8]. Tiek VZV, tiek HSV sukelti encefalitai imunosupresijos metu gali pasireikšti be leukocitų skaičiaus padidejjimo likvore $[7,11,14,20]$. Likvoro PGR dèl VZV pasižymi kur kas mažesniu jautrumu nei HSV PGR tyrimas, todèl kai kurie autoriai rekomenduoja kartu atlikti ir likvoro antikūnų prieš VZV tyrimą, tačiau iki šiol nėra galutinio sutarimo dèl konkrečios VZV encefalito nustatymo metodikos ir tyrimų interpretacijos [21].

Citomegalo viruso (CMV) sukeltas encefalitas beveik išskirtinai išsivysto tik imunosupresiniams ligoniams [21]. Rizika susirgti CMV encefalitu ypač išauga ligoniams po kaulų čiulpų transplantacijos, užsikrètusiems ŽIV ir tiems, kuriems taikoma galvos smegenų navikų radioterapija [22]. Pastariesiems ligoniams CMV encefalitas gali išsivystyti dar nebaigus radioterapijos kurso, o su CMV infek- cija susijusi encefalopatija dažnai klaidingai priskiriama šalutiniam radioterapijos poveikiui $[23,24]$. CMV encefalitu sergantiems ligoniams dažniausiai pasireiškia poūmis kognityvinių ir žievinių funkcijų sutrikimas bei tokie simptomai, kaip mieguistumas ir traukuliai. MRT vaizduose dažniausiai matomi dauginiai didelio intensyvumo taškiniai židiniai su difuzijos restrikcija. Pažeidimo židiniai dažniausiai lokalizuojasi žievėje supratentoraliai ir po ependima, tačiau kartais gali būti matomi požievyje ar infratentoraliai. CMV encefalito diagnozè patvirtinama likvore nustačius CMV DNR [8, 25].

Žmogaus herpes viruso 6 (angl. Human Herpesvirus 6, HHV-6) paplitimas yra globalus. Iprastai HHV-6 infekcija persergama vaikystejje, ypač retai pasireiškiant CNS pažeidimo simptomams. Imunosupresinių ligonių, kuriems atlikta alogeninè kaulų čiulpų transplantacija, viruso reaktyvacija smegenyse gali pasireikšti ūmiu žaibinès eigos potransplantaciniu limbiniu encefalitu (angl. posttransplantation acute limbic encephalitis, PALE), ypač per pirmąsias tris gydymo savaites. Būdingi klinikiniai HHV-6 sukelto limbinio encefalito simptomai yra anterogradinè amnezija ir traukulinè būklè [26]. MRT vaizduose matomi hiperintensiniai signalai T2 sekoje kaktinių ar momeninių skilčių baltojoje medžiagoje bei smilkininių sričių ir limbinès sistemos struktūrų edema [8]. HHV-6 gebejjimas integruotis ị šeimininko ląstelių genetinę medžiagą ir globalus šio viruso paplitimas apsunkina HHV-6 encefalito laboratorinę diagnostiką. Sukèlejui nustatyti ir diagnozei patvirtinti siūloma matuoti ne tik likvoro, bet ir kraujo HHV-6 DNR lygị, kuris turètų būti mažesnis nei $6,0 \log ^{10}$ kopi$\mathrm{ju} / \mathrm{ml}$, siekiant atmesti chromosomose integruotos viruso DNR replikaciją, kuri nėra kliniškai reikšminga [21, 27].

Mūsų aprašomo ligonio somatinio ištyrimo metu bèrimų nestebèta, vis dèlto, ịvertinus esamą Lietuvos epidemiologinę situaciją, reikètų ịtarti ir tymų viruso sukeliamą encefalitą. Jam būdingas etapinis makulopapulinis kūno bėrimas, Filatovo-Kopliko dėmės skruostų gleivinèje ir kiti tymų infekcijos klinikiniai požymiai. Tymų viruso sukeltas CNS pažeidimas skirstomas ị keturis tipus. Pirmasis tipas - pirminis tymų sukeltas encefalitas. Jis pasireiškia atsiradus bėrimui 1-3 iš 1000 tymais sergančių ligonių. Pirminiam encefalitui būdingas karščiavimas, galvos skausmas, sutrikusi sąmonès būklè ir traukuliai [28]. Mirštamumas nuo pirminio encefalito siekia 10-15\%, o kas ketvirtam išgyvenusiam stebimi liekamieji neurologiniai reiškiniai [29]. MRT vaizduose stebimi hiperintensiniai židiniai T2 sekoje ir smegenų edema. Antrasis tipas - ūmus poinfekcinis encefalomielitas, kuris dažniausiai pasireiškia praejus kelioms savaitėms ar mėnesiams nuo bėrimo atsiradimo, jo dažnis - 1 iš 1000 tymų atvejų. Manoma, kad tymų sukeltas ūmus poinfekcinis encefalomielitas yra autoimuninès kilmès, todèl ligos metu virusas likvore neaptinkamas. Ūminiam poinfekciniam encefalomielitui būdingas karščiavimas, židininiai neurologiniai simptomai ir traukuliai. MRT T2 sekoje matomi hiperintensiniai daugybiniai židiniai galvos ir nugaros smegenyse, ypač baltojoje medžiagoje [30]. Trečiasis tipas - poūmis encefalitas, dar vadinamas ūmiu inkliuzinių kūnelių encefalitu (angl. 
acute inclusion body encephalitis). Tai reta tymų sukelto neurologinio pažeidimo forma, kuri išskirtinai pasireiškia imunosupresiniams ligoniams. Poūmio encefalito pasireiškimo laikas, skirtingų šaltinių duomenimis, svyruoja nuo 5 savaičių iki vienerių metų nuo pirminès tymų infekcijos [30-32]. Aprašytuose klinikiniuose atvejuose poūmis encefalitas dažniausiai pasireiškia sutrikusia sąmonès būkle, židininiais traukuliais, neretai atspariais gydymui, ir hemiplegija. Antikūnai prieš tymų virusą poūmio encefalito metu likvore aptinkami $50 \%$ ligos atvejų. Ligos prognozė yra itin bloga - mirštamumas siekia $76 \%$, o neurologinis deficitas, kai kurių autorių duomenimis, pasireiškia visiems išgyvenusiems ligoniams [32]. Ketvirtasis pažeidimo tipas - poūmis sklerozuojantis panencefalitas (SSPE) (angl. sclerosing subacute panencephalitis), kuris dažniausiai išsivysto praejjus 4-8 metams po pirminès infekcijos. Svarbiausias rizikos faktorius SSPE išsivystyti iki antrujų gyvenimo metų persirgta tymų infekcija. SSPE būdinga klastinga klinikinè eiga: vos pastebimi asmenybès pokyčiai, prastejjantys kognityviniai sugebejjimai ir motorikos sutrikimai, kartais - traukuliai. Šie simptomai lètai progresuoja iki sunkaus sąmonès sutrikimo, vėliau ištinka koma ir mirtis [8]. SSPE metu MRT vaizduose gali būti matoma židininė leukodistrofija ir difuzinė žievinè atrofija [30]. Tymų viruso sukeltų encefalitų (išskyrus ūmų poinfekcinį encefalomielitą) diagnozė patvirtinama likvore nustačius antikūnus prieš tymų virusą arba PGR metodu aptikus tymų RNR [8].

Progresuojanti multifokalinė leukoencefalopatija (PML) - tai John Cunningham viruso (JCV) reaktyvacijos sąlygota oportunistinè demielinizuojanti centrinès nervų sistemos infekcija [33]. JCV aprašomam ligoniui mažai tikėtina, esant teigiamam atsakui ị gydymą antibiotikais, tačiau PML galima būtų įtarti nesant gydymo efekto. Užsikrètusių JCV skaičius Europoje svyruoja nuo 48,8 iki $69,5 \%$ [34]. JCV imunosupresinių ligonių galvos smegenyse infekuoja oligodendrocitus bei astrocitus, pažeidžia baltają medžiagą, daug rečiau - pilkają [33]. PML kliniškai pasireiškia motorinių ir sensorinių funkcijų, regos ir kalbos sutrikimais. Išplitus požieviniam pažeidimui, gali atsirasti elgesio pokyčių, kognityvinių ir psichiatrinių sutrikimų, kurie dažniausiai išsivysto kartu su motorine ar sensorine disfunkcija [35]. PML infekcija dažnai pasireiškia galvos skausmu, eisenos sutrikimais, iki $20 \%$ atvejų traukuliais, tačiau karščiavimas nèra būdingas PML simptomas $[35,36]$. MRT vaizduose dažnai stebimi didesni nei $3 \mathrm{~cm}$ dauginiai susiliejantys požieviniai ar jukstakortikaliniai židiniai, dažniausiai pažeidžiama kaktinė skiltis ir parietookcipitalinė sritis, labai retai - žievė. PML metu likvore gliukozės koncentracija atitinka normą, dažniausiai nustatomas normalus leukocitų skaičius, retai - vidutiniškai padidejjęs [37]. Jei likvoro JCV PGR yra neigiamas, diagnozė patvirtinama atliekant smegenų biopsiją ir histologini bei molekulinị bioptato ištyrimą $[8,21]$.

Prancūzijos multicentrinio perspektyvinio tyrimo duomenimis, $M$. tuberculosis yra dažniausias bakterinio encefalito (meningoencefalito) sukèlejas [4]. CNS infekcija yra sunkiausia ekstrapulmoninè tuberkuliozès išraiška, susiju- si su dideliu mirštamumu ir sunkiais liekamaisiais neurologiniais reiškiniais. Nors tuberkuliozinis encefalitas yra vienas dažniausių bakterinių encefalitų, literatūroje trūksta duomenų apie šio patogeno sukeliamą galvos smegenų pažeidimą. Viename iš aprašytų $M$. tuberculosis sukelto encefalito tyrimų, infekcija atvykimo ị ligoninę metu dažniausiai pasireikšdavo dezorientacija, dizartrija ir kitais židininiais neurologiniais simptomais. Tik 20 \% ligonių buvo stebimi kvėpavimo takų pažeidimo simptomai. Visiems ligoniams likvore nustatytas padidèjęs baltymo kiekis (mediana - 2,1 g/l), pleocitozè (mediana - 150 ląstelių/ $/ \mathrm{mm}^{3}$ ), o $89 \%$ ligonių - sumažèjęs gliukozès kiekio likvore ir kraujyje santykis [4, 38]. Neuroinvazinès tuberkuliozės diagnozei patvirtinti naudojama Gramo būdu dažyto likvoro preparato mikroskopija ir likvoro pasèlis [8].

L. monocytogenes yra antras pagal dažnị bakterinio encefalito sukèlèjas. L. monocytogenes sukeltas encefalitas yra susijęs su dideliu mirštamumu, ypač ligoniams, turintiems keletą sunkių gretutinių ligų. Didžiausia rizika neuroinvazinei listeriozei išsivystyti pasižymi vyresnio nei $65 \mathrm{~m}$. amžiaus žmonès (rizika auga didejjant ligonio amžiui), imunosupresiniai ligoniai ir nėščiosios [4]. Naujausiais literatūros duomenimis, net 52 \% ligonių, kuriems diagnozuotas L. monocytogenes encefalitas, buvo imunosupresuoti, o dažniausia imunosupresijos priežastis - ilgalaikis kortikosteroidų vartojimas (67 \%). Dažniausi neurologiniai pažeidimo simptomai, atvykus ị ligoninę, buvo: hemiparezè (40\%), smegenèlinè ataksija (39\%), n. facialis paralyžius (37\%), eisenos sutrikimai (32\%) ir nistagmas (28\%) [39]. L. monocytogenes sukelto encefalito metu likvore dažniausiai randamas padidèjęs leukocitų skaičius (mediana - 310 ląstelių/ $\mathrm{mm}^{3}$ ), dominuojant limfocitams, padidèjęs baltymo kiekis (mediana - 2,3 g/l) ir sumažèjusi gliukozès koncentracija (75\% atvejų) [4]. Galvos smegenų MRT vaizduose dažniausiai nustatomi hiperintensiniai židiniai T2 sekoje (81 \%), kontrastinès medžiagos kaupimas (60\%) bei židinių kontrasto kaupimas žiedu (46 \%). Dažniausia pažeidimų lokalizacija - smegenų kamienas (55\%), supratentorinė baltoji medžiaga (25\%) ir smegenèlių pusrutuliai (20\%) [39]. Encefalito diagnozė patvirtinama nustačius $L$. monocytogenes augimą likvoro pasėlyje [8]. Nors aprašomam ligoniui diagnozuotas bakterinis meningoencefalitas, minèti du dažniausi ir kiti bakteriniai sukèlèjai nebuvo nustatyti.

Siekiant, kad infekcinio encefalito diagnozè imunosupresinès būklès ligoniui būtų nustatyta laiku, reikia kruopščiai surinkti anamnezę, išsiaiškinti gretutines ligas, vartojamus vaistus. Aprašytas ligonis sirgo mielomine liga, ị kurios gydymo protokolą buvo ịtraukti ciklofosfamidas, talidomidas ir deksametazonas - vaistai, pasižymintys sisteminiu imunosupresiniu poveikiu. Verta pabrėžti, kad CNS infekcijų išsivystymo rizika skiriasi taikant sistemini imunosupresinị ir imunomoduliacinį gydymą. Pastarasis yra susijęs su mažesne rizika, nes gydymo taikinys yra ne visa imuniné sistema, o tik vienas ar keli imuninès sistemos komponentai [40]. Ūmiai išsivysčiusi židininè neurologinė simptomatika be karščiavimo ir meninginès simptomatikos gali imituoti ūmų galvos smegenų kraujotakos sutri- 
kimą. Mūsų aprašytu atveju ligonis pateko ị insulto centrą, kuriame insulto specialistas diagnozavo galvos smegenų insultą. Tolimesnè ligos eiga ir atlikti tyrimai leido paneigti insulto diagnozę ir nustatyti bakterinị meningoencefalitą. Klinicistui vertètų prisiminti diferencinès diagnostikos aspektus, nes neuroinfekcijos klinika, imunosupresijos atveju, gali būti netipinè. Nuodugnus somatinis ligonio ištyrimas, esant infekcijos požymių už CNS ribų, tokių kaip bėrimo elementai odoje, gali praversti susiaurinant tikėtinu ligos sukèlèjų sąrašą. Vis dẻlto ekstracerebrinių infekcijos požymių, galinčių padèti susiaurinti diferencinę diagnostiką, aprašytam ligoniui stebėta nebuvo, o po plataus ligonio ištyrimo ligos sukèlèjas išliko neaiškus.

Teisingas neurologinės būklès įvertinimas, laboratorinių ir instrumentinių tyrimų interpretavimas imunosupresijos metu yra didelis iššūkis gydytojui. Esant imunosupresinei organizmo būklei, mažèja ląstelinis ir humoralinis imuninis atsakas ị puolančius patogenus, dèl to sumažèja dalies laboratorinių tyrimų jautrumas, pavyzdžiui, infekcinio encefalito metu kraujyje esant leukocitopenijai, likvore pleocitozės gali ir nebūti. Dėl tos pačios priežasties pakinta ir patologinio proceso išraiška radiologiniuose galvos smegenų vaizduose. Infekcijos pažeistos smegenų dalys gali imituoti insulto vaizdą ar suklaidinti gydytoją, vertinantị smegenyse matomų pažeidimo židinių atsiradimo laiką. Tyrimų interpretavimą gali apsunkinti ir ligonio vartojami vaistai ar patirti traukulių priepuoliai: gydymas kortikosteroidais sumažina vaizdiniuose tyrimuose naudojamų kontrastinių medžiagų efektyvumą, o po keleto traukulių epizodų MRT FLAIR sekoje gali būti matomi kliniškai nereikšmingi, tačiau klaidinantys smegenų parenchimos pakitimo židiniai. Verta pabrèžti ir tai, kad imunosupresiniams ligoniams padidejjusio intrakranijinio spaudimo požymiai neretai yra kur kas silpniau išreikšti, todèl prieš juosmeninę punkciją GSKT yra rekomenduojama visiems imunosupresiniams ligoniams [5].

\section{GYDYMAS}

Kadangi HSV yra dažniausias infekcinio encefalito sukèlèjas, o uždelsta gydymo pradžia yra susijusi su blogesne neurologine ir išgyvenimo prognoze, rekomenduojama pradèti priešvirusini gydymą intraveniniu acikloviru (10 mg/kg kas 8 val.) visiems ligoniams, kuriems pasireiškia encefalito simptomai ir atlikta juosmeninè punkcija, nelaukiant likvoro PGR tyrimo atsakymo [8, 41]. PGR tyrimas dažniausiai atliekamas per 24 valandas nuo simptomų pradžios, tačiau, atliekant PGR labai ankstyvoje ligos stadijoje, HSV DNR kartais neaptinkama. Nepaisant neigiamo PGR tyrimo, esant būdingai HSV encefalito klinikai ir vaizdiniams tyrimams, gydymas acikloviru turètu būti tęsiamas, o juosmeninė punkcija ir likvoro PGR tyrimas pakartoti ketvirtą ligos dieną [42, 43]. Standartiné HSV encefalito gydymo acikloviru trukmè yra 14-21 diena, tačiau imunosupresiniams ligoniams gydymą galima tęsti atsižvelgiant ị klinikinị atsaką ir laboratorinius duomenis $[26,42]$. Nors literatūroje yra duomenų, kad korti- kosteroidai gali būti susiję su didesniu išgyvenamumu, vis dėlto jų skyrimas HSV encefalito metu išlieka prieštaringas dèl randomizuotų klinikinių tyrimų trūkumo. VZV sukeltas encefalitas, kaip ir HSV encefalitas, gydomas intraveniniu acikloviru $10 \mathrm{mg} / \mathrm{kg}$ kas 8 val. Nėra sutarimo dèl optimalios gydymo trukmès. Rekomenduojama gydyti 10-14 dienų [42].

CMV sukeltą encefalitą, patvirtinus diagnozę PGR tyrimu, rekomenduojama gydyti foskarneto $(90 \mathrm{mg} / \mathrm{kg}$ infuzija kas 12 val.) ir gancikloviro $(5 \mathrm{mg} / \mathrm{kg}$ infuzija kas 12 val.) deriniu [44]. CMV encefalito gydymas šiuo deriniu yra efektyvesnis nei foskarneto ar gancikloviro skyrimas atskirai, tačiau svarbu pabrèžti, kad toks gydymas pasižymi dideliu toksiškumu, taip pat trūksta klinikinių tyrimų CMV encefalito gydymo efektyvumui ịrodyti [25, 26].

Patvirtinto gydymo HHV-6 infekcijai nèra. Šiuo metu gydymo metodai remiasi mažo ịrodymo lygio atvejų aprašymais ir juose vartotais vaistais: gancikloviru, foskarnetu, cidofoviru ir brincidofoviru. Limbinị encefalitą siūloma gydyti gancikloviro infuzija, kurio pradinè dozè $-5 \mathrm{mg} / \mathrm{kg}$ kas 12 val., palaikomoji - $5 \mathrm{mg} / \mathrm{kg} / \mathrm{d}$., arba foskarneto infuzija, kurio pradinè dozé - $60 \mathrm{mg} / \mathrm{kg}$ kas 8 val., palaikomoji - 90-120 mg/kg/d.; gydymas tęsiamas 14-21 dieną, tačiau gali būti ir pratęstas, atsižvelgiant ị klinikinị atsaką bei laboratorinius duomenis [26]. Literatūros duomenimis, didejja HHV-6 atsparumas ganciklovirui. Esant neefektyviam gydymui gancikloviru, rekomenduojama HHV-6 sukeltą encefalitą gydyti foskarnetu [26, 45].

Efektyvaus gydymo tymų sukeltam encefalitui nèra. Literatūroje aprašomi klinikiniai atvejai, kai imunosupresiniams ligoniams skyrus intraveninio ribavirino stebèta trumpesnè ligos eiga ir geresnès ligos išeitys, tačiau patikimų ịrodymų šio gydymo efektyvumui patvirtinti dar trūksta. Skyrus gydymą ribavirinu, rekomenduojama gydymo trukmè - 2-3 savaitės [8]. Aprašyti pavieniai SSPE gydymo atvejai, skiriant ribaviriną intraventrikuliariai. Viename tokių tyrimų klinikinis pagerejjimas stebètas keturiems iš penkių aprašytų ligonių, tačiau svarbu pabrèžti, kad reikalingi tolimesni tokio gydymo efektyvumo ir saugumo tyrimai [46].

Specifinio PML gydymo kol kas nėra, tačiau naujausioje literatūroje aprašomas pirmasis sėkmingas onkohematologinio ligonio gydymas nivolumabu - užprogramuotos ląstelès žūties baltymo 1 inhibitoriumi (angl. programmed cell death protein-1 inhibitor). Išgijimas patvirtintas smegenų biopsija [47]. İtakos geresnei neurologinei ir išgyvenimo prognozei turi imunosupresijos lygio mažinimas, keičiant imunosupresinių vaistų dozę (mažinant ar nutraukiant) ar skiriant antiretrovirusinị gydymą iki tol jo negavusiems ŽIV ligoniams [48].

Uždelstas neuroinvazinès tuberkuliozès gydymas yra susijęs su padidejusiu mirštamumu ir blogesnèmis neurologinėmis išeitimis, ypač senyvo amžiaus ligonių ir ligonių su hidrocefalija bei smegenų išemija grupèse [21, 49]. Dèl lèto $M$. tuberculosis augimo pasėliuose ir mažo greitųju diagnostinių testų jautrumo, empirinę terapiją siūloma pradèti visiems ligoniams, kurių klinikiniai požymiai ir simptomai bei likvoro tyrimas atitinka galimą tuberkuliozès 
2 lentelè. Infekciniu encefalitu diagnostikos ir gydymo apibendrinimas

\begin{tabular}{|c|c|c|}
\hline Infekcinio encefalito sukèlèjas & Diagnostika & Gydymas \\
\hline Herpes simplex & DNR nustatymas likvore (PGR). & $\begin{array}{l}\text { Acikloviras } 10 \mathrm{mg} / \mathrm{kg} \text { kas } 8 \text { val., ì veną } 14-21 \mathrm{~d} ., \text { esant } \\
\text { poreikiui, gydymo trukmę rekomenduojama pratęsti. }\end{array}$ \\
\hline Varicella zoster & $\begin{array}{l}\text { DNR nustatymas likvore (PGR), } \\
\text { anti-VZV IgM antikūnų nustatymas } \\
\text { likvore. }\end{array}$ & $\begin{array}{l}\text { Acikloviras } 10 \mathrm{mg} / \mathrm{kg} \text { kas } 8 \text { val., į veną. Nėra } \\
\text { sutarimo dèl optimalios gydymo trukmès. } \\
\text { Rekomenduojama gydyti } 10-14 \mathrm{~d} .\end{array}$ \\
\hline Human herpes virus-6 & $\begin{array}{l}\text { DNR nustatymas likvore (PGR), DNR } \\
\text { kopijų skaičiaus nustatymas kraujo } \\
\text { serume (PGR). } \\
\text { - Gydymas skiriamas ir DNR } \\
\text { nustatymas likvore laikomas } \\
\text { reikšmingu, kai DNR kopijų skaičius } \\
\text { kraujyje }-<6,0 \log ^{10} / \mathrm{ml} \text {. }\end{array}$ & $\begin{array}{l}\text { Patvirtinto gydymo nèra. } \\
\text { Limbiniam encefalitui gydyti gali būti naudojama } \\
\text { gancikloviro infuzija, pradinė dozè - } 5 \mathrm{mg} / \mathrm{kg} \text { kas } \\
12 \text { val., palaikomoji }-5 \mathrm{mg} / \mathrm{kg} / \mathrm{p} \text {. } \\
\text { ARBA foskarneto infuzija, pradinė dozè }-60 \mathrm{mg} / \mathrm{kg} \\
\text { kas } 8 \text { val., palaikomoji - } 90-120 \mathrm{mg} / \mathrm{kg} / \mathrm{d} \text {. Gydymo } \\
\text { trukmè - } 14-21 \text { diena. }\end{array}$ \\
\hline Citomegalo virusas & DNR nustatymas likvore (PGR). & $\begin{array}{l}\text { Patvirtinto gydymo nėra. } \\
\text { Foskarneto ( } 90 \mathrm{mg} / \mathrm{kg} \text { infuzija kas } 12 \mathrm{val} .) \text { ir gancik- } \\
\text { loviro ( } 5 \mathrm{mg} / \mathrm{kg} \text { infuzija kas } 12 \text { val.) derinys. }\end{array}$ \\
\hline John Cunningham virusas & $\begin{array}{l}\text { DNR nustatymas likvore (PGR), retais } \\
\text { atvejais - smegenų biopsija. }\end{array}$ & $\begin{array}{l}\text { Patvirtinto gydymo nėra. } \\
\text { İtakos geresnei neurologinei ir išgyvenimo prognozei } \\
\text { turi imunosupresijos lygio mažinimas, keičiant } \\
\text { imunosupresinių vaistų dozę (mažinant ar } \\
\text { nutraukiant) ar skiriant antiretrovirusinį gydymą iki } \\
\text { tol jo negavusiems ŽIV ligoniams. }\end{array}$ \\
\hline Tymai & $\begin{array}{l}\text { RNR nustatymas likvore (PGR), IgM anti- } \\
\text { kūnų prieš tymų virusą nustatymas likvore. } \\
\text { - Metodai netinka ūmiam poinfekciniam } \\
\text { encefalomielitui nustatyti. }\end{array}$ & $\begin{array}{l}\text { Patvirtinto gydymo nėra. } \\
\text { Ūmiam inkliuzinių kūnelių encefalitui gydyti gali } \\
\text { būti naudojamas intraveninis ribavirinas. Gydymo } \\
\text { trukmè - 2-3 savaitės. }\end{array}$ \\
\hline M. tuberculosis & Likvoro mikroskopija ir likvoro pasèlis. & $\begin{array}{l}\text { Encefalitas gydomas keturių vaistų deriniu } 2 \text { ménesius: } \\
\text { izoniazidu }-5 \mathrm{mg} / \mathrm{kg} / \mathrm{d} \text {, rifampicinu }-10 \mathrm{mg} / \mathrm{kg} / \mathrm{d} \text {, } \\
\text { pirazinamidu }-30 \mathrm{mg} / \mathrm{kg} / \mathrm{d} \text { (maksimali dozé }-2 \mathrm{~g} \text { ) ir } \\
\text { etambutoliu }-20 \mathrm{mg} / \mathrm{kg} / \mathrm{d} \text {. Praejjus dviem mėnesiams } \\
\text { po gydymo keturių vaistu deriniu, gydymas tęsiamas } \\
\text { rifampicino ir izoniazido deriniu dar 7-10 mėnesių. }\end{array}$ \\
\hline L. monocytogenes & Likvoro ir kraujo pasèlis. & $\begin{array}{l}\text { Amoksicilinas } 200 \mathrm{mg} / \mathrm{kg} / \mathrm{d}, 21 \mathrm{~d} \text {. ir gentamicinas } \\
5-6 \mathrm{mg} / \mathrm{kg} / \mathrm{d} \text { pirmas penkias dienas. }\end{array}$ \\
\hline
\end{tabular}

diagnozę, nelaukiant laboratorinio ligos sukèlèjo patvirtinimo [42]. M. tuberculosis sukeltas encefalitas gydomas keturių vaistų deriniu 2 mènesius: izoniazidu $-5 \mathrm{mg} / \mathrm{kg} / \mathrm{d}$, rifampicinu - $10 \mathrm{mg} / \mathrm{kg} / \mathrm{d}$, pirazinamidu - $30 \mathrm{mg} / \mathrm{kg} / \mathrm{d}$ (maksimali dozè - $2 \mathrm{~g}$ ) ir etambutoliu - $20 \mathrm{mg} / \mathrm{kg} / \mathrm{d}$. Praèjus dviem mėnesiams po gydymo keturių vaistų deriniu, gydymas tęsiamas rifampicino ir izoniazido deriniu dar 7-10 mėnesių. Taip pat neuroinvazinės tuberkuliozės metu suaugusiesiems 4 savaites rekomenduojama papildomai skirti $0,4 \mathrm{mg} / \mathrm{kg} / \mathrm{d}$ deksametazono, kurio dozè mažinama per dar 4 savaites [50].

Nustatyta, kad netinkama pradinè antibiotikų terapija neuroinvazinès listeriozės metu yra nepriklausomas mirštamumą didinantis rizikos veiksnys, todèl ankstyva diagnostika ir tinkamų antimikrobinių vaistų skyrimas, sergant L. monocytogenes sukeltu encefalitu. yra ypač svarbūs [51]. Mokslinejje literatūroje duomenys apie amoksicilino ir gentamicino derinio pranašumą, gydant neuroinvazinę listeriozę, yra prieštaringi. Nors šie antibiotikai veikia sinergistiškai, dažniausiai nėra stebimas reikšmingas antibiotikų derinio pranašumas, lyginant su amoksicilino monoterapija [42]. Nepaisant to, rekomenduojama skirti $2 \mathrm{~g}$ pradinę amoksicilino infuziją per $30 \mathrm{~min}$., toliau tęsiant amoksiciliną $200 \mathrm{mg} / \mathrm{kg} / \mathrm{d}$, dozę padalinant ị 4-6 intravenines infuzijas (gydymo trukmé - $21 \mathrm{~d}$.), kartu skiriant intraveninę gentamicino infuziją $5-6 \mathrm{mg} / \mathrm{kg} / \mathrm{d}$ (gydymo trukmè - 5 d.) $[8,42]$. Jei ligonis yra alergiškas beta laktaminiams antibiotikams, rekomenduojama ligoni gydyti kotrimoksazoliu 21 dieną [42].

\section{IŠVADOS}

1. Imunosupresinių būklių atveju infekcinio encefalito diagnostika yra sudėtinga dèl netipinès klinikos ir silpnai išreikštų laboratorinių bei instrumentinių tyrimų pokyčių.

2. Meningoencefalitas imunosupresiniams ligoniams gali pasireikšti insultui būdinga klinika - ūmia židinine neurologine simptomatika be karščiavimo ar meninginių simptomų.

3. Laiku diagnozavus bakterinị meningoencefalitą ir skubiai paskyrus intensyvų gydymą antibiotikais, imunosupresinès būklès ligonis gali pasveikti be liekamųų reiškinių. 


\section{Literatūra}

1. Venkatesan A, Michael BD, Probasco JC, et al. Acute encephalitis in immunocompetent adults. Lancet 2019; 393: 702-16. https://doi.org/10.1016/S0140-6736(18)32526-1

2. George BP, Schneider EB, Venkatesan A. Encephalitis hospitalization rates and inpatient mortality in the United States, 2000-2010. PLoS One 2014; 9: e104169. https://doi.org/ 10.1371/journal.pone.0104169

3. Granerod J, Cousens S, Davies NWS, et al. New estimates of incidence of encephalitis in England. Emerg Infect Dis 2013; 19: 1455-62. https://doi.org/10.3201/eid1909.130064

4. Mailles A, Stahl J-P. Infectious encephalitis in France in 2007: a national prospective study. Clin Infect Dis 2009; 49: 1838-47. https://doi.org/10.1086/648419

5. Pruitt AA. Central nervous system infections complicating immunosuppression and transplantation. Contin Lifelong Learn Neurol 2018; 24: 1370-96. https://doi.org/10.1212/ CON.0000000000000653

6. Singh TD, Fugate JE, Rabinstein AA. The spectrum of acute encephalitis: causes, management, and predictors of outcome. Neurology 2015; 84: 359-66. https://doi.org/10.1212/ WNL.0000000000001190

7. Saylor D, Thakur K, Venkatesan A. Acute encephalitis in the immunocompromised individual. Curr Opin Infect Dis 2015; 28: 330-6. https://doi.org/10.1097/QCO.0000000000000175

8. Tunkel AR, Glaser CA, Bloch KC, et al. The management of encephalitis: clinical practice guidelines by the Infectious Diseases Society of America. Clin Infect Dis 2008; 47: 303-27. https://doi.org/10.1086/589747

9. Venkatesan A, Tunkel AR, Bloch KC, et al. Case definitions, diagnostic algorithms, and priorities in encephalitis: consensus statement of the international encephalitis consortium. Clin Infect Dis 2013; 57: 1114-28. https://doi.org/10.1093/ cid/cit458

10. Fine AJ, Sorbello A, Kortepeter C, et al. Central nervous system herpes simplex and varicella zoster virus infections in natalizumab-treated patients. Clin Infect Dis 2013; 57: 849-52. https://doi.org/10.1093/cid/cit376

11. Tan IL, McArthur JC, Venkatesan A, et al. Atypical manifestations and poor outcome of herpes simplex encephalitis in the immunocompromised. Neurology 2012; 79: 2125-32. https://doi.org/10.1212/WNL.0b013e3182752ceb

12. Graber JJ, Rosenblum MK, Deangelis LM. Herpes simplex encephalitis in patients with cancer. J Neurooncol 2011; 105: 415-21. https://doi.org/10.1007/s11060-011-0609-2

13. Schiff D, Rosenblum MK. Herpes simplex encephalitis (HSE) and the immunocompromised: a clinical and autopsy study of HSE in the settings of cancer and human immunodeficiency virus-type 1 infection. Hum Pathol 1998; 29: 215-22. https://doi.org/10.1016/S0046-8177(98)90038-7

14. Jakob NJ, Lenhard T, Schnitzler P, et al. Herpes simplex virus encephalitis despite normal cell count in the cerebrospinal fluid. Crit Care Med 2012; 40: 1304-8. https://doi.org/10.1097/CCM.0b013e3182374a34

15. Meyding-Lamadé U, Strank C. Herpesvirus infections of the central nervous system in immunocompromised patients. Ther Adv Neurol Disord 2012; 5: 279-96. https://doi.org/ $10.1177 / 1756285612456234$

16. Redelman-Sidi G, Michielin O, Cervera C, et al. ESCMID Study Group for Infections in Compromised Hosts $(\mathrm{ESGICH})$ Consensus Document on the safety of targeted and biological therapies: an infectious diseases perspective (Immune checkpoint inhibitors, cell adhesion inhibitors, sphingosine-1-phosphate receptor modulators and proteasome inhibitors). Clin Microbiol Infect 2018; 24: S95-107. https://doi.org/10.1016/j.cmi.2018.01.030

17. Keystone EC, Kavanaugh AF, Sharp JT, et al. Radiographic, clinical, and functional outcomes of treatment with adalimumab (a human anti-tumor necrosis factor monoclonal antibody) in patients with active rheumatoid arthritis receiving concomitant methotrexate therapy: a randomized, placebo-controlled, 52-week trial. Arthritis Rheum 2004; 50: 1400-11. https://doi.org/10.1002/art.20217

18. Nabi S, Kahlon P, Goggins M, et al. VZV encephalitis following successful treatment of CMV infection in a patient with kidney transplant. BMJ Case Rep 2014; 2014: bcr2014206655. https://doi.org/10.1136/bcr2014-206655

19. König C, Kleber M, Reinhardt H, et al. Incidence, risk factors, and implemented prophylaxis of varicella zoster virus infection, including complicated varicella zoster virus and herpes simplex virus infections, in lenalidomide-treated multiple myeloma patients. Ann Hematol 2014; 93: 479-84. https://doi.org/10.1007/s00277-013-1951-6

20. Nagel MA, Jones D, Wyborny A. Varicella zoster virus vasculopathy: the expanding clinical spectrum and pathogenesis. J Neuroimmunol 2017; 308: 112-7. https://doi.org/10.1016/j.jneuroim.2017.03.014

21. Fillatre P, Crabol Y, Morand P, et al. Infectious encephalitis: management without etiological diagnosis 48 hours after onset. Med Mal Infect 2017; 47: 236-51. https://doi.org/ 10.1016/j.medmal.2017.02.004

22. Arribas JR, Storch GA, Clifford DB, et al. Cytomegalovirus encephalitis. Ann Intern Med 1996; 125: 577-87. https://doi.org/10.7326/0003-4819-125-7-199610010-00008

23. Goerig NL, Frey B, Korn K, et al. Frequent occurrence of therapeutically reversible CMV-associated encephalopathy during radiotherapy of the brain. Neuro Oncol 2016; 18: 1664-72. https://doi.org/10.1093/neuonc/now120

24. Goerig N, Semrau S, Frey B, et al. Clinically significant CMV (re)activation during or after radiotherapy/chemotherapy of the brain. Strahlentherapie und Onkol 2016; 192: 489-97. https://doi.org/10.1007/s00066-016-0987-7

25. Steiner I, Budka H, Chaudhuri A, et al. Viral meningoencephalitis: a review of diagnostic methods and guidelines for management. Eur J Neurol 2010; 17: 999-1009. https://doi.org/10.1111/j.1468-1331.2010.02970.x

26. Baldwin KJ, Cummings CL. Herpesvirus infections of the nervous system. Contin Lifelong Learn Neurol 2018; 24: 1349-69. https://doi.org/10.1212/CON.0000000000000661

27. Ward KN, Hoe NL, Thiruchelvam AD, et al. Human herpesvirus 6 DNA levels in cerebrospinal fluid due to primary infection differ from those due to chromosomal viral integration and have implications for diagnosis of encephalitis. J Clin Microbiol 2007; 45: 1298-304. https://doi.org/ 10.1128/JCM.02115-06

28. Hosoya M. Measles encephalitis: direct viral invasion or autoimmune-mediated inflammation? Intern Med 2006; 45: 841-2. https://doi.org/10.2169/internalmedicine.45.0161

29. Ota MO, Moss WJ, Griffin DE. Emerging diseases: measles. J Neurovirol 2005; 11: 447-54. https://doi.org/10.1080/ 13550280591002441

30. Buchanan R, Bonthius DJ. Measles virus and associated central nervous system sequelae. Semin Pediatr Neurol 2012; 19: 107-14. https://doi.org/10.1016/j.spen.2012.02.003 
31. Perry RT, Halsey NA. The clinical significance of measles: a review. J Infect Dis 2004; 189: S4-16. https://doi.org/ $10.1086 / 377712$

32. Baldolli A, Dargère S, Cardineau E, et al. Measles inclusionbody encephalitis (MIBE) in a immunocompromised patient. J Clin Virol 2016; 81: 43-6. https://doi.org/10.1016/ j.jcv.2016.05.016

33. Zhai S, Brew BJ. Progressive multifocal leukoencephalopathy. Neurol Clin 2018; 152: 127-37. https://doi.org/ 10.1016/B978-0-444-63849-6.00010-4

34. Bozic C, Subramanyam M, Richman S, et al. Anti-JC virus (JCV) antibody prevalence in the JCV Epidemiology in MS (JEMS) trial. Eur J Neurol 2014; 21: 299-304. https://doi.org/10.1111/ene.12304

35. Berger JR, Pall L, Lanska D, et al. Progressive multifocal leukoencephalopathy in patients with HIV infection. J Neurovirol 1998; 4: 59-68. https://doi.org/10.3109/ 13550289809113482

36. Lima MA, Drislane FW, Koralnik IJ. Seizures and their outcome in progressive multifocal leukoencephalopathy. Neurology 2006; 66: 262-4. https://doi.org/10.1212/01.wnl. 0000194227.16696 .11

37. Berger JR, Aksamit AJ, Clifford DB, et al. PML diagnostic criteria: consensus statement from the AAN neuroinfectious disease section. Neurology 2013; 80: 1430-8. https://doi.org/10.1212/WNL.0b013e31828c2fa1

38. Honnorat E, De Broucker T, Mailles A, et al. Encephalitis due to Mycobacterium tuberculosis in France. Med Mal Infect 2013 ; 43: 230-8. https://doi.org/10.1016/j.medmal. 2013.05.003

39. Arslan F, Ertan G, Emecen AN, et al. Clinical presentation and cranial MRI findings of listeria monocytogenes encephalitis: a literature review of case series. Neurologist 2018; 23: 198-203. https://doi.org/10.1097/NRL.0000000000000212

40. Williamson EML, Berger JR. Central nervous system infections with immunomodulatory therapies. Contin Lifelong Learn Neurol 2015; 21: 1577-98. https://doi.org/10.1212/ CON.0000000000000245

41. Solomon T, Michael BD, Smith PE, et al. Management of suspected viral encephalitis in adults - Association of British Neurologists and British Infection Association National Guidelines. J Infect 2012; 64: 347-73. https://doi.org/ 10.1016/j.jinf.2011.11.014

42. Goulenok T, Buzelé R, Duval X, et al. Management of adult infectious encephalitis in metropolitan France. Med Mal Infect 2017; 47: 206-20. https://doi.org/10.1016/j.medmal. 2017.01.006

43. Poissy J, Wolff M, Dewilde A, et al. Factors associated with delay to acyclovir administration in 184 patients with herpes simplex virus encephalitis. Clin Microbiol Infect 2009; 15: 560-4. https://doi.org/10.1111/j.1469-0691.2009.02735.x

44. Kaplan JE, Benson C, Holmes KK, et al. Guidelines for prevention and treatment of opportunistic infections in HIV-infected adults and adolescents: recommendations from CDC, the National Institutes of Health, and the HIV Medicine Association of the Infectious Diseases Society of America. MMWR Recomm Rep 2009; 58: 1-207. https://doi.org/ 10.1037/e537722009-001

45. Baldwin K. Ganciclovir-resistant Human herpesvirus-6 encephalitis in a liver transplant patient: a case report. J Neurovirol 2011; 17: 193-5. https://doi.org/10.1007/ s13365-011-0019-4
46. Hosoya M, Mori S, Tomoda A, et al. Pharmacokinetics and effects of ribavirin following intraventricular administration for treatment of subacute sclerosing panencephalitis. Antimicrob Agents Chemother 2004; 48: 4631-5. https://doi.org/10.1128/AAC.48.12.4631-4635.2004

47. Hoang E, Bartlett NL, Goyal MS, et al. Progressive multifocal leukoencephalopathy treated with nivolumab. J Neurovirol 2019; 2: 284-7. https://doi.org/10.1007/ s13365-019-00738-x

48. Bartsch T, Rempe T, Leypoldt F, et al. The spectrum of progressive multifocal leukoencephalopathy: a practical approach. Eur J Neurol 2019; 26(4): 566-e41. https://doi.org/ 10.1111/ene.13906

49. Brancusi F, Farrar J, Heemskerk D. Tuberculous meningitis in adults: a review of a decade of developments focusing on prognostic factors for outcome. Future Microbiol 2012; 7: 1101-16. https://doi.org/10.2217/fmb.12.86

50. Thwaites G, Fisher M, Hemingway C, et al. British Infection Society guidelines for the diagnosis and treatment of tuberculosis of the central nervous system in adults and children. J Infect 2009; 59: 167-87. https://doi.org/10.1016/j.jinf. 2009.06.011

51. Pelegrín I, Moragas M, Suárez C, et al. Listeria monocytogenes meningoencephalitis in adults: analysis of factors related to unfavourable outcome. Infection 2014; 42: 817-27. https://doi.org/10.1007/s15010-014-0636-y

\section{Jokubaitis, J. Valaikienė}

\section{INFECTIOUS ENCEPHALITIS DIAGNOSIS AND TREATMENT IN IMMUNOSUPRESSED PATIENTS: A CASE REPORT AND REVIEW OF LITERATURE}

\section{Summary}

Infectious encephalitis in immunosuppressed patients is a common and urgent condition that requires rapid diagnosis and early treatment. The disease can lead to severe neurological deficit and eventually result in the death of the patient. Usually infectious encephalitis presents with fever, headache, focal neurological deficits, and altered state of consciousness. Immunosuppressed patients pose a great differential diagnostic challenge since clinical symptoms, laboratory findings, and imaging tests are often attenuated and may imitate stroke or other non-infectious diseases. Therefore, infectious meningoencephalitis should be suspected in all immunosuppressed patients with acute focal neurological symptoms, even in the absence of fever and meningeal signs. Accordingly, physician should thoroughly evaluate patient's history, perform detailed physical examination, and carefully interpret test results. Early diagnosis and initiation of appropriate treatment of bacterial meningoencephalitis correlates with better prognosis for the patient. This article describes an atypical clinical case of a bacterial meningoencephalitis with stroke-like symptoms in a patient with multiple myeloma. In addition, the article reviews clinical presentation, diagnostic and treatment recommendations of infectious encephalitis in immunosuppressed patients.

Keywords: neuroinfection, encephalitis, immunosuppression, diagnosis, treatment.

Gauta:

Priimta spaudai:

20190705 20190709 